\title{
Analisis praktek Samsa>rah (makelar) dalam Jual Beli Sepeda Motor di Kabupaten Bone
}

\author{
Sopyan \\ Institut Agama Islam Negeri (IAIN) Bone \\ Sopyaniainbone@yahoo.co.id \\ Yaman \\ Sekolah Tinggi Agama Islam (STAl) Al -Furqan Makassar \\ yamaniainbone@gmail.com
}

\begin{abstract}
The purpose of this study was to find out how brokers practice in buying and selling motorbikes in bone district, how the contract forms in the practice of buying and selling motorbikes in bone district, to find out the views of academics and scholars about the practice of brokers in buying and selling motorbikes in Bone Regency. The results showed that the realtor practice in buying and selling motorbikes in bone district is that the seller gives full authority to the broker to sell motorbikes because the seller does not want to bother with everything, usually the seller only wants to get a clean sale price without deducting costs. In such cases, the seller does not need to meet the buyer because everything will be dealt with by an intermediary trader. An intermediary trader (broker) is not only an intermediary and the seller can also buy and sell motorbikes. Brokers are not just intermediaries in buying and selling activities but can also be buyers because they are interested in the condition of the motorcycle, and will then be sold again so that the intermediary trader will no longer take wages from the sale transaction but will profit from motorcycle sales.
\end{abstract}

Keywords: Broker, Buy and Sell, Motorcycle

\begin{abstract}
Abstrak
Tujuan penelitian ini adalah untuk mengetahui bagaimana praktek makelar dalam jual beli sepeda motor di kabupaten bone, bagaimana bentuk akad dalam praktek jual beli sepeda motor di kabupaten bone, untuk mengetahui bagaimana pandangan akademisi dan ulama tentang praktek makelar dalam
\end{abstract}

Jurnal Ilmiah Al Tsarwah

Program Magister Program Studi Ekonomi Syariah

Institut Agama Islam Negeri (IAIN) Bone 
jual beli sepeda motor di Kabupaten Bone. Hasil penelitian menunjukkan bahwapraktek makelar dalam jual beli sepeda motor di kabupaten bone yaitu Penjual memberikan kuasa sepenuhnya kepada makelar untuk menjualkan sepeda motor karena penjual tidak ingin repot dengan segala sesuatunya, biasanya penjual hanya ingin langsung mendapat harga penjualan bersih tanpa dipotong dengan biaya-biaya. Dalam hal yang demikian maka penjual tidak perlu bertemu dengan pembeli karena segala sesuatunya akan diuruskan oleh pedagang perantara.Seorang pedagang perantara(makelar) selain berkedudukan sebagai perantara dan penjual bisa juga sebagai pihak yang membeli sekaligus menjual sepeda motor. Makelar bukan hanya menjadi perantara dalam kegiatan Jual beli akan tetapi dapat juga sebagai pembeli karena tertarik terhadap kondisi sepeda motor tersebut, dan kemudian akan dijual lagi sehingga pedagang perantara ini tidak lagi mengambil upah dari transaksi jual beli akan tetapi akan mengambil laba dari penjualan sepeda motor.

Kata Kunci: Makelar, Jual Beli, Sepeda Motor

\section{PENDAHULUAN}

Makelar (samsa>rah) merupakan perantara perdagangan (orang yang menjualkan barang atau mencarikan pembeli), Atau perantara antara penjual dan pembeli untuk memudahkan jual beli. ${ }^{1}$ Badan perantara dalam jual beli disebut pula simsar, yaitu seseorang yang menjualkan barang orang lain atas dasar bahwa seseorang itu akan diberi upah oleh yang punya barang sesuai dengan usahanya.

Makelar dalam bahasa Arab disebut samsa>rah yang berarti perantara perdagangan atau perantara antara penjual dan pembeli untuk memudahkan jual-beli. Lebih lanjut Samsarah adalah kosakata bahasa Persia yang telah diadopsi menjadi bahasa Arab yang berarti sebuah profesi

${ }^{1}$ M. Ali. Hasan,Masail Fiqhiyah,Ed. 1 (Cet. 2; Jakarta: PT Raja GrafindoPersada, 1997), h. 87. 
dalam menengahi dua kepentingan atau pihak yang berbeda dengan kompensasi berupa upah (ujroh) dalam menyelesaikan suatu transaksi. Secara umum samsaraha dalah perantara perdagangan (orang yang menjualkan barang dan mencarikan pembeli), atau perantara antara penjual dan pembeli untuk memudahkan jual-beli. Dengan adanya perantara maka pihak penjual dan pembeli akan lebih mudah dalam bertransaksi, baik transaksi berbentuk jasa maupun berbentuk barang. Pekerjaan makelar (samsa>rah) dalam fiqih Islam termasuk akad ija>rah, yaitu suatu transaksi memanfaatkan jasa orang lain dengan imbalan. Al-ija>rah berasal dari kata al-ajru yang berarti al-iwa>dhu (ganti). Dari se itu atstsa>wab (pahala) dinamai ajru (upah).

Praktek makelar dalam jual beli sepeda motor di Kabupaten Bone yaitu Penjual memberikan kuasa sepenuhnya kepada makelar untuk menjualkan sepeda motor karena penjual tidak ingin repot dengan segala sesuatunya, biasanya penjual hanya ingin langsung mendapat harga penjualan bersih tanpa dipotong dengan biaya-biaya. Dalam hal yang demikian maka penjual tidak perlu bertemu dengan pembeli karena segala sesuatunya akan diuruskan oleh pedagang perantara. Seorang pedagang perantara (makelar) selain berkedudukan sebagai perantara dan penjual bisa juga sebagai pihak yang membeli sekaligus menjual sepeda motor. Makelar bukan hanya menjadi perantara dalam kegiatan Jual beli akan tetapi dapat juga sebagai pembeli karena tertarik terhadap kondisi sepeda motor tersebut, dan kemudian akan dijual lagi sehingga pedagang perantara ini tidak lagi mengambil upah dari transaksi jual belia kan tetapi akan mengambil laba dari penjualan sepeda motor.

Masyarakat menggunakan jasa pedagang perantara atau makelar, karena disibukkan dengan pekerjaan masing-masing, sehingga tidak ada 
waktu untuk menjual barang dagangannya atau mencari barang yang diperlukannya. ada pula orang yang waktunya lapang, tidak sibuk. Namun tidak mempunyai keahlian untuk memasarkan (menjualkan) barangnya, atau tidak tahu bagaimana cara memperoleh barang yang diperlukannya itu. Untuk memudahkan kesulitan yang dihadapi, pada saat ini ada orang yang profesinya khusus menangani hal-hal yang di kemukakan diatas yang merupakan biro jasa yang menangani berbagai kegiatan. ${ }^{2}$ Dalam persoalan ini, kedua belah pihak mendapat manfaat. Bagi makelar (perantara), atau biro jasa mendapat lapangan pekerjaan dan uang jasa dari hasil pekerjaannya itu. Demikian juga orang yang memerlukan jasa mereka, mendapat kemudahan, karena ditangani oleh orang yang mengerti betul dalam bidang pekerjaan semacam ini, mengandung unsur tolong-menolong yang saling menguntungkan. Dengan demikian pekerjaan tersebut tidak ada cacat dan celanya dan sejalan dengan ajaran islam. ${ }^{3}$

Islam mensyariatkan jual-beli dengan wakil karena manusia membutuhkannya. Tidak semua manusia berkemampuan untuk menekuni segala urusannya secara pribadi. la membutuhkan kepada pendelegasian mandat orang lain untuk melakukannya sebagai wakil darinya yaitu orang menjalankan usaha sebagai perantara, yakni perantara antara penjual dan pembeli untuk melaksanakan transaksi jual beli. Diantara tuntunan AlQur'a>n tentang tata cara berjual beli yang baik, sebagaimana firman Allah Dalam Al-Qur'a>n surat Al-Baqarah ayat 275 :

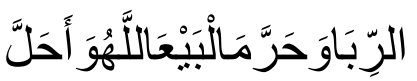

${ }^{2}$ lbid.

${ }^{3} /$ bid., h. 88. 
Terjemahnya: Allah telah menghalalkan jual-beli dan mengharamkan riba. $^{4}$

Allah menegaskan bahwa telah dihalalkan jual beli dan diharamkan riba. Orang-orang yang membolehkan riba dapat ditafsirkan sebagai pembantahan hukum-hukum yang telah ditetapkan oleh allah yang maha mengetahui lagi maha bijaksana. Riba yang dahulu telah dimakan sebelum turunnya firman allah ini, apabila pelakunya bertaubat, tidak ada kewajiban untuk mengembalikan dan dimaafkan oleh allah. Sedangkan bagi siapa saja yang kembali lagi kepada riba setelah menerima larangan dariallah, maka mereka adalah penghuni neraka dan mereka kekal di dalamnya.

Profesi makelar tidak boleh disalahgunakan seperti untuk menjual atau mencari barang yang dilarang oleh agama. Ringkasnya semua barang yang dilarang memperjualbelikannya, jangan melibatkan diri kedalamnya, walaupun imbalannya besar. Se hasil yang diperoleh dari usaha yang demikian, juga haram dimanfaatkan. Banyak kaum muslimin yang mengabaikan mempelajari muamalah, mereka melalaikan aspek ini, sehingga tidak peduli mereka memakan barangharam, sekalipun semakin hari usahanya kian meningkat dan keuntungan semakin banyak. Sebagaimana diketahui jual-beli berlangsung dengan ija>b dan $q a>b u l$, adanya rukun jual-beli, dan syarat yang lainnya. ${ }^{5}$

Ajaran islam dalam persoalan muamalah bukanlah ajaran yang kaku, sempit dan jumud, melainkan suatu ajaran yang fleksibel dan elastis, yang dapat mengakomodir berbagai perkembangan transaksi modern,

${ }^{4}$ Depertemen Agama Islam, Al-Quran dan Terjemahannya, (Bandung : Syaamil AlQuran, 1995), h. 47.

${ }^{5}$ Abdul Aziz Muhammad Azzam, Fiqh Muamalat Sistem Transaksi dalam Fiqh Islam, Ed. 1 (Cet. 1; Jakarta: AMZAH, 2010), h. 28. 
selama tidak bertentangan dengan nash Al-Qur'a>n dan sunnah. ${ }^{6}$ Misalnya, dalam persoalan jual-beli, utang piutang, kerjasama dagang, perserikatan, kerjasama dalam penggarapan tanah, dan sewa-menyewa. ${ }^{7}$

Berdasarkan uraian tersebut, penulis tertarik pada makelar yang ada di kabupaten bone, kaitannya dengan jual beli barang yang mana seorang makelar mempunyai peran aktif dalam memasarkan sepeda motor tersebut, baik dalam menerima pesanan, penawaran harga, sampai pada perolehan laba dari hasil negosiasi transaksi sepeda motor. Biasanya dalam posisi seorang makelar itu adalah sebagai penghubung antara kedua belah pihak tetapi di sisi lain ada juga makelar yang mencari kehuntungan yang berlebihan dengan penambahan harga barang, menutupi cacat barang, sehingga makelar menekan pihak penjual dan pembeli untuk mendapatkan kehuntungan sebanyak-banyaknya. Dengan demikian penulis melakukan penelitian tentang analisis praktek samsa>rah (makelar) dalam jual beli sepeda motor di Kabupaten Bone. Berdasarkan latar belakang yang telah diuraikan diatas, dapat diambil rumusan masalah sebagai berikut Bagaimana praktek makelar dalam jual beli sepeda motor di Kabupaten Bone, Bagaimana bentuk akad dalam praktek makelar jual beli sepeda motor di Kabupaten Bone dan Bagaimana pandangan akademisi dan ulama tentang praktek makelar jual beli sepeda motor di Kabupaten Bone.

\section{METODE}

\section{Teknik Analisis Data}

\footnotetext{
5.

${ }^{7}$ lbid., h. 7.

${ }^{6}$ Nasrun Haroen, Fiqh Muamalah, (Cet. 2; Jakarta : gaya media pratama, 2007), h. 
Untuk menganalisis data-data yang telah dikumpulkan, maka teknik analisis data yang digunakan yaitu teknik reduksi data, model data(data display), dan penarikan/verifikasi kesimpulan.

Reduksi data merujuk pada proses pemilihan, pemokusan, penyederhanaan, abstraksi, dan pentransformasian data mentah yang terjadi dalam catatan-catatan lapangan tertulis. Sebagaimana kita ketahui, reduksi data terjadi secara kontinu melalui kehidupan suatu proyek yang diorientasikan secara kualitatif. ${ }^{8}$

Langkah kedua dari kegiatan analisis data adalah model data. Kita mendefinisikan model sebagai suatu kumpulan informasi yang tersusun yang membolehkan pendeskripsian kesimpulan dan pengambilan tindakan. Model (displays) dalam kehidupan sehari-hari berbeda-beda dari pengukur bensin, surat kabar, sampai layar computer. Melihat sebuah tayangan membantu kita memahami apa yang terjadi dan melakukan sesuatu analisis lanjutan atau tindakan didasarkan pada pemahaman tersebut. ${ }^{9}$

Langkah ketiga dari aktivitas analisis adalah penarikan dan verifikasi kesimpulan. Dari permulaan pengumpulan data, penelitian kualitatif mulai memutuskan apakah makna sesuatu, mencatat keteraturan, pola-pola, penjelasan, konfigurasi yang mungkin, alur kausal, dan proposisi-proposisi. Kesimpulan akhir mungkin tidak terjadi hingga pengumpulan data selesai, tergantung pada ukuran korpus dari catatan lapangan, pengodean, penyimpanan, dan metode-metode perbaikan yang digunakan. ${ }^{10}$

Tabel 1

Langkah-langkah Analisis Data

${ }^{8}$ Emzir, Metodologi Penelitian Kualitatif:Analisis Data, Ed. 1 (Cet. 4 ; Jakarta: Rajawali Pers, 2014), h. 129.

${ }^{9}$ lbid., h. 131.

10 lbid., h. 133. 


\begin{tabular}{|l|l|l|}
\hline o. & \multicolumn{1}{|c|}{ Langkah } & \multicolumn{1}{|c|}{ Implementasi } \\
\hline & Data collection & $\begin{array}{l}\text { Melakukan observasi, wawancara } \\
\text { dengan dengan informen dari makelar di } \\
\text { kabupaten bone mengenai pokok } \\
\text { permasalahan yang dibahas. }\end{array}$ \\
\hline & Reduksi data & $\begin{array}{l}\text { Menelah seluruh hasil observasi, } \\
\text { wawancara, dokumentasi, buku-buku untuk } \\
\text { menghasilkan hal-hal pokok yang berkaitan } \\
\text { dengan penelitian. }\end{array}$ \\
\hline Display data & $\begin{array}{l}\text { Menyusum hal-hal pokok yang suda } \\
\text { dirangkum secara sistematis untuk } \\
\text { memperoleh data secara jelas mengenai } \\
\text { permasalahan dalam penelitian ini. }\end{array}$ \\
\hline Verification & $\begin{array}{l}\text { Memberikan makna dari data yang } \\
\text { delah dikumpulkan dengan membuat } \\
\text { kesimpulan mengenai praktek makelar } \\
\text { dalam jual beli sepeda motor. }\end{array}$ \\
\hline
\end{tabular}

HASIL PENELITIAN DAN PEMBAHASAN

\section{Praktek Makelar Dalam Jual Beli Sepeda Motor Di Kabupaten Bone}

Makelar merupakan perantara bagi manusia untuk melakukan sebuah transaksi, serta untuk mendapatkan sesuatu yang dibutuhkan dalam memenuhi kebutuhan sehari-hari. Makelar juga sangat menolong bagi sesama umat manusia. Makelar atau katakanlah perantara dalam perdagangan, di zaman kita ini sangat penting artinya dibandingkan dengan masa-masa yang telah lalu, karena terikatnya perhubungan perdagangan antara importer dan produser, antara pedagang kolektif dan antara pedagang 
perorangan. Sehingga makelar dalam hal ini mempunyai peran yang sangat penting sekali.

Dari hasil wawancara yang dilakukan penulis makelar sepeda motor di Kabupaten Bone yang berada di lokasi penelitian dengan memenuhi kriteria yang telah ditetapkan, maka diperoleh penelitian data yang diperlukan, yaitu

a. Makelar Sepeda Motor Di Bone Kota

Tugas dari kami (makelar) ketika melayani para pemesan (penjual dan pembeli) adalah menerima pekerjaan dari pengguna jasa makelar yaitu penjual dan pembeli, menanyakan barang yang dipesan biasanya meliputi (harga, jenis, dan kualitas dari sepeda motor). Setiap penjualan, makelar mendapat kehuntungan sesuai dengan kualitas motor yang dipasarkan. Makelar bekerjasama dengan pembiayaan seperti mandala, karena di pembiayaan itu ada motor yang kredit macet, disini makelar bertugas untuk memasarkan motor yang kredit macet tersebut."11

Dalam menjual motor harus memakai kwitansi dengan materai 600 beserta tanda tangan lalu di berikan kepada pembeli, serta harus ada bpkb, stnk, kondisi kendaraan, kwitansi, harga yang ditawarkan, setiap penjualan motor setiap hari tidak menentu kadang cuma 1 motor yang dipasarkan bahkan bisa mencapai 5 motor dalam 1 hari. Adapun keuntungan yang diperoleh dalam penjualan 1 sepeda motor sekitar 500.000 bahkan bisa mencapai $800.000 .{ }^{\prime 12}$

\footnotetext{
${ }^{11}$ Hasil Wawancara Dengan Syam Pemilik Makelar Sepeda Motor, Pada Hari Minggu 2 Oktober 2016 Jam 10.00 - 10.15 WIB, Di Kelurahan Masumpu Kecamatan Tanete Riattang Barat.

${ }^{12}$ Hasil Wawancara Dengan Jusri Pemilik Makelar Sepeda Motor, Pada Hari Minggu 2 Oktober 2016 Jam 10.35 - 10.50 WIB, Di Kelurahan Masumpu Kecamatan Tanete Riattang Barat.
} 
Pelaksanaan jual beli sepeda motor melayani kas dan kredit, usaha ini milik sendiri, setiap penjualan minimal 4 sepeda motor yang terjual dalam sebulan, persyaratan yang harus dipenuhi dalam menjual sepeda motor yaitu ada stnk, bpkb, dan kondisi sepeda motor, keuntungan yang diperoleh rata-rata 4.00 .000 perbulan." ${ }^{13}$

b. Makelar Sepeda Motor Di Bone Bagian Barat

Dalam prakteknya ketika ada yang mau menjual motornya kepada kami harus memenuhi persyaratan yaitu: kelengkapan suratsurat seperti bpkb, stnk, serta dari kualitas motor dalam menentukan harga. Ketika ada yang mau membeli motor kepada kami, terkandang pembeli langsung ketempat kami dan ada pula pembeli untuk diantarkan sepeda motor yang akan dibeli ke alamat pembeli tersebut. Dalam sebulan rata-rata sepeda motor yang terjual di tempat kami ratarata 5 sepeda motor. ${ }^{14}$

Penjual dan pembeli datang ketempat kami untuk membeli ataupun menjual motornya, terkadang pembeli pembeli ingin membeli sepeda motor dengan menelpon saja kepada kami, persyaratan untuk menjual ataupun membeli sepeda motor yaitu: kelengkapan surat kendaraan seperti stnk, bpkb, serta kualitas motor, rata-rata dalam sebulan sepeda motor yang terjual di tempat kami yaitu 2 sepeda motor. ${ }^{15}$

Pelaksanaan jual beli melayani kas dan kredit, usaha ini milik sendiri, persyaratan yang harus dipenuhi dalam mengambil kredit

\footnotetext{
${ }^{13}$ Hasil Wawancara Dengan Bastian Pemilik Makelar Sepeda Motor, Pada Hari Minggu 2 Oktober 2016 Jam 11.10 - 11.20 WIB, Di Kelurahan Masumpu Kecamatan Tanete Riattang Barat.

${ }^{14}$ Hasil Wawancara Dengan Muh. Jasbah Pemilik Makelar Sepeda Motor, Pada Hari Sabtu 1 Oktober 2016 Jam 10.22- 10.32 WIB, Di Desa Usa Kecamatan Palakka.

${ }^{15} \mathrm{Hasil}$ Wawancara Dengan Herman Pemilik Makelar Sepeda Motor, Pada Hari Sabtu 1 Oktober 2016 Jam 10.40-11.55 WIB, Di Desa Usa Kecamatan Palakka.
} 
sepeda motor yaitu: ktp suami istri, kartu keluarga, penjamin (orang tua), bpkb, gesekan per unit (cek pisik), rekening listrik. Dalam penjualan sepeda motor minimal 15 sepeda motor yang terjual dalam sebulan. ${ }^{16}$

c. Makelar Sepeda Motor Di Bone Bagian Selatan

Penjual dan pembeli datang ketempat kami untuk menjual atau membeli sepeda motor, kadang kami mengantarkan sepeda motor kepada pembeli. Penjual datang ketempat kami untuk menjual motornya dan penentuan harganya tergantung kualitas sepeda motor yang akan di jual, kalau sudah sepakat harganya maka kami membeli dan menjualnya kembali kepada pembeli dan mendapatkan keuntungan dari hasil penjualannya. Persyaratan dalam menjual ataupun membeli sepeda motor yaitu stnk, bpkb,serta kondisi motor. Kami melayani kas dan kredit, kalau ada yang kredit kami bekerjasama dengan pembiayaan seperti mandala, adira. ${ }^{17}$

Dalam prakteknya pembeli dan penjual datang ketempat kami, dan ada pula pembeli yang minta diantarkan sepeda motor yang akan dibelinya, dan kami pula biasanya keluar untuk mencari orang yang mau membeli sepeda motor, persyaratan dalam menjual ataupun membeli yaitu : kelayakan surat-surat kendaraan seperti stnk, bpkb, kondisi motor, system penjualannya yaitu kas dan kredit, jika ada pembeli yang mau kredit kami bekerjasama dengan pembiayaan yaitu: adira finance. ${ }^{18}$

\footnotetext{
${ }^{16}$ Hasil Wawancara Dengan Uddin Pemilik Makelar Sepeda Motor, Pada Hari Selasa 4 Oktober 2016 Jam 10.30-12.45 WIB, Di Desa liliriawang Kecamatan Bengo.

${ }^{17}$ Hasil Wawancara Dengan Anis Amir Pemilik Makelar Sepeda Motor, Pada Hari Sabtu 1 Oktober 2016 Jam 12.30-12.45 WIB, Di Desa Kawarang Kecamatan Cina.

${ }^{18} \mathrm{Hasil}$ Wawancara Dengan Herman Pemilik Makelar Sepeda Motor, Pada Hari Sabtu 1 Oktober 2016 Jam 13.00 - 13.15 WIB, Di Kelurahan Tanete Kecamatan Cina.
}

Jurnal Ilmiah Al Tsarwah Program Magister Program Studi Ekonomi Syariah Institut Agama Islam Negeri (IAIN) Bone 
Penjual dan pembeli datang ketempat kami untuk membeli ataupun menjual sepeda motor, kadang kami keluar mencari orang yang mau membeli sepeda motor. Kalau ada pembeli yang mau kredit kami bawah ke bri, dan rata-rata motor yang terjual dalam sebulan yaitu 5 sepeda motor, persyaratan dalam menjual atau membeli yaitu stnk, dan bpkb sepeda motor. ${ }^{19}$

\section{d. Makelar Sepeda Motor Di Bone Bagian Utara}

Pihak kami menghubungi pihak pertama (pembeli) dengan membawa sepeda motor yang didapat dari penjual, setelah itu kemudian mendatangi pihak penjual untuk melangsungkan transaksi. Didalam transaksi itu pun terjadi tawar-menawar, didalam tawar menawar seorang makelar ikut aktif. Setelah sepeda motor jadi untuk dibeli atau terjadi kesepakatan pihak pertama (pembeli) dan pihak kedua (penjual) maka pihak ketiga (makelar). ${ }^{20}$

Penjual dan pembeli datang ketempat kami untuk menjual atau membeli sepeda motor, kadang kami mengantarkan sepeda motor kepada pembeli. Pelaksanaan jual beli menggunakan kas dan kredit dengan persyaratan kelengkapan surat kendaraan bermotor yaitu: stnk, bpkb, serta kondisi motor. Dalam sebulan kami menjual sepeda motor rata-rata 10 unit sepeda motor. ${ }^{21}$

e. Makelar Sepeda Motor Di Bone Bagian Timur

Calon pembeli mendatangi ke tempat kami dengan maksud meminta untuk dicarikan sepeda motor, didalam pembicaraan itu yang

\footnotetext{
${ }^{19}$ Hasil Wawancara Dengan Safrinus Pemilik Makelar Sepeda Motor, Pada Hari Sabtu 1 Oktober 2016 Jam 14.00-14.15 WIB, Di Desa Mario Kecamatan Mare.

${ }^{20} \mathrm{Hasil}$ Wawancara Dengan Anwar Pemilik Makelar Sepeda Motor, Pada Hari Rabu 5 Oktober 2016 Jam 10.00 - 10.15 WIB, Di Desa Paccing Kecamatan Awangpone.

${ }^{21}$ Hasil Wawancara Dengan Rijal Pemilik Makelar Sepeda Motor, Pada Hari Rabu 5 Oktober 2016 Jam 10.30 - 10.45 WIB, Di Desa Paccing Kecamatan Awangpone. 
diutarakan adalah tentang keadaan barang yang lebih dulu, kemudian kualitas dan harga sepeda motor, setelah itu dilanjutkan dengan saling berikrar atau melakukan akad antara kedua belah pihak untuk mencarikan barang yang di pesan calon pembeli. Berikutnya setelah terjadinya akad, kami mencari barang dari seorang penjual, setelah mendapatkan maka pihak kami menghubungi pihak pertama (pembeli) dengan membawa sepeda motor yang didapat dari penjual, setelah itu kemudian mendatangi pihak penjual untuk melangsungkan transaksi. Didalam transaksi itu pun terjadi tawar-menawar, Setelah sepeda motor jadi untuk dibeli atau terjadi kesepakatan pihak pertama (pembeli) dan pihak kedua (penjual) maka pihak ketiga (makelar). ${ }^{22}$

Ketika penjual dan pembeli datang ketempat kami, mengenai maksudnya yaitu menjual dan membeli, maka ketika seorang ada yang mau membeli motor di tempat kami, proses transaksi tersebut sedikit lama, dikarenakan terlebih dahulu mengadakan tawar-menawar antara penjual dan pembeli secara langsung dan menghasilkan kesepakatan dalam jual-beli sepeda motor. Di bagian ini proses yang jadi pegangan atau patokan adalah mengenai kualitas sepeda motor, kelengkapan surat-surat seperti bpkb dan stnk, Adapun mengenai, harga itu disesuaaikan dengan barang tersebut. Dan ketika sudah ada kesepakatan maka selanjutnya adalah proses pembayaran dari pembeli ke penjual. ${ }^{23}$

${ }^{22}$ Hasil Wawancara Dengan Indri Pemilik Makelar Sepeda Motor, Pada Hari Sabtu 8 Oktober 2016 Jam 9.30 - 9.45 WIB, Di Kelurahan Lonrae Kecamatan Tanete Riattang Timur.

${ }^{23}$ Hasil Wawancara Dengan Amri Pemilik Makelar Sepeda Motor, Pada Hari Sabtu 8 Oktober 2016 Jam 9.55 - 10.10 WIB, Di Kelurahan Lonrae Kecamatan Tanete Riattang Timur.

Jurnal Ilmiah Al Tsarwah Program Magister Program Studi Ekonomi Syariah Institut Agama Islam Negeri (IAIN) Bone 
Dari penjelasan makelar sepeda motor di Kabupaten Bone dapat disimpulkan bahwa Kegiatan pedagang perantara dalam melakukan transaksi jual beli sangat sederhana karena lebih mengutamakan musyawarah mufakat terhadap pihak pembeli ataupun penjual, ketika ada kesepakatan maka pedagang perantara akan menyiapkan segala sesuatunya untuk mendukung transaksi. Pedagang perantara akan meminta penjual untuk menyiapkan berkas-berkas yang meliputi :

(1) Bukti Pemilik Kendaraan Bermotor (BPKB). (2) Surat Tanda Nomor Kendaraan (STNK). (3) Kwitansi tanda beli motor untuk bukti bahwa penjual telah menerima pembayaran dari pembeli dari setiap transaksi per unit motor. Rata- rata para makelar sepeda motor di kabupaten bone bekerjasama dengan pembiayaan seperti mandala, adira. Pedagang perantara akan selalu berbuat agar antara pembeli dan penjual mengadakan pendekatan yang baik sehingga dapat menumbuh kembangkan minat penjual dan pembeli untuk melakukan transaksi jual beli, baik menjual ataupun membeli sepeda motor yang nantinya bertujuan agar transaksi jual beli dapat berjalan dengan baik.

\section{Bentuk Akad Dalam Praktek Makelar Dalam Jual Beli Sepeda Motor}

Setelah pemaparan mengenai praktek seorang makelar, maka untuk selanjutnya adalah bentuk akad, bentuk akad dari transaksi tersebut adalah berbentuk akad waka>lah (perwakilan) yaitu mewakilkan atau menyerahkan sesuatu pekerjaan atau urusan kepada orang lain, dan gambaran transaksi tersebut adalah sebagai berikut, dua belah pihak melakukan kesepakatan, yaitu pihak Makelar menyewakan jasa tenaganya kepada pihak lainnya (pembeli dan penjual). Dengan cara ketika habis masa sewa yaitu barang yang di cari sudah di dapatkan. Pada bentuk pembayarannya tidak dengan 
menggunakan uang panjer atau uang muka, melainkan ketika selesai kesepakatan maka diikuti pula pembayaran dari pembeli kepada penjual dan diserahkannya sepeda motor dari penjual kepada pembeli, serta upah bagi makelar.

\section{a. Makelar Sepeda Motor Di Bone Kota}

Adapun akad yang dijadikan pengikat pada perjanjian adalah berbentuk akad waka>lah (perwakilan), dari seorang penjual kepada makelar dan pembeli kepada makelar misalnya : Saya ada sepeda motor mau dijual, dan saya hargai sepeda motor ini 9 juta rupiah, maka juallah sepeda motor ini, selanjutnya terserah anda mau jual berapa itu terserah anda, kalau ada laba maka laba tersebut jadi milik anda" kemudian makelar menjawab "ya"sebagai kesanggupan untuk menjualkan sepeda motor. ${ }^{24}$

Di dalam pelaksanaan jual beli sepeda motor di tempat kami, bentuk akadnya adalah akad waka>lah yaitu: mewakilkan atau menyerahkan sesuatu pekerjaan atau urusan kepada orang lain. Misalnya: ada orang yang datang ketempat kami untuk menjual motornya, dan dia minta kepada kami untuk dicarikan pembeli sepeda motor. ${ }^{25}$

Proses akadnya berbentuk akad waka>lah (perwakilan), bahwa ketika kami (makelar, penjual dan pembeli), melakukan akad dalam transaksi jual beli sepeda motor para pelaku memahami dari perkataan

\footnotetext{
${ }^{24}$ Hasil Wawancara Dengan M. Darwis Pemilik Makelar Sepeda Motor, Pada Hari Minggu 2 Oktober 2016 Jam 10.00 - 10.15 WIB, Di Kelurahan Masumpu Kecamatan Tanete Riattang Barat.

${ }^{25}$ Hasil Wawancara Dengan Jusri Pemilik Makelar Sepeda Motor, Pada Hari Minggu 2 Oktober 2016 Jam 10.35 - 10.50 WIB, Di Kelurahan Masumpu Kecamatan Tanete Riattang Barat.
}

Jurnal Ilmiah Al Tsarwah Program Magister Program Studi Ekonomi Syariah Institut Agama Islam Negeri (IAIN) Bone 
tersebut yang terkandung maksud memasarkan, mencari, dan mendapatkan barang (sepeda motor). ${ }^{26}$

b. Makelar Sepeda Motor Di Bone Bagian Barat

Pelaksanaan jual beli sepeda motor di tempat kami, bentuk akadnya adalah: akad waka>lah yaitu: mewakilkan atau menyerahkan sesuatu pekerjaan atau urusan kepada orang lain. Misalnya: ada orang yang datang ketempat kami untuk menjual motornya, dan dia minta kepada kami untuk dicarikan pembeli atau dijualkan sepeda motornya. ${ }^{27}$

Di dalam pelaksanaan jual beli sepeda motor di tempat kami, bentuk akadnya yaitu: akad waka>lah yaitu: mewakilkan atau menyerahkan sesuatu pekerjaan atau urusan kepada orang lain. Misalnya: ada orang yang datang ketempat kami untuk menjual motornya, dan dia minta kepada kami untuk dicarikan pembeli sepeda motor. ${ }^{28}$

Akadnya jual beli sepeda motor di tempat kami, berbentuk akad waka>lah (perwakilan), bahwa ketika kami sebagai makelar dalam melakukan akad dalam transaksi jual beli sepeda motor para pelaku memahami dari perkataan tersebut yang terkandung maksud mencari, dan mendapatkan barang (sepeda motor). ${ }^{29}$

c. Makelar Sepeda Motor Di Bone Bagian Selatan

Jual beli sepeda motor di tempat kami pelaksanaan akadnya berbentuk akad waka>lah (perwakilan). Misalnya: ada orang yang

${ }^{26}$ Hasil Wawancara Dengan Bastian Pemilik Makelar Sepeda Motor, Pada Hari Minggu 2 Oktober 2016 Jam 11.10 - 11.20 WIB, Di Kelurahan Masumpu Kecamatan Tanete Riattang Barat.

${ }^{27}$ Hasil Wawancara Dengan Muh. Jasbah Pemilik Makelar Sepeda Motor, Pada Hari Sabtu 1 Oktober 2016 Jam 10.22- 10.32 WIB, Di Desa Usa Kecamatan Palakka.

${ }^{28}$ Hasil Wawancara Dengan Herman Pemilik Makelar Sepeda Motor, Pada Hari Sabtu 1 Oktober 2016 Jam 10.40-11.55 WIB, Di Desa Usa Kecamatan Palakka.

${ }^{29}$ Hasil Wawancara Dengan Uddin Pemilik Makelar Sepeda Motor, Pada Hari Selasa 4 Oktober 2016 Jam 10.30-12.45 WIB, Di Desa liliriawang Kecamatan Bengo.

Jurnal Ilmiah Al Tsarwah Program Magister Program Studi Ekonomi Syariah Institut Agama Islam Negeri (IAIN) Bone 
datang ketempat kami untuk menjual motornya, dan dia minta kepada kami untuk dicarikan pembeli sepeda motor. ${ }^{30}$

Pelaksanaan jual beli sepeda motor di tempat kami, bentuk akadnya yaitu: akad waka>lah (perwakilan). Misalnya: ada penjual yang datang ketempat kami untuk menjual motornya, dan penjual meminta kepada kami untuk dijualkan motornya ataupun dicarikan pembeli sepeda motor. ${ }^{31}$

Bentuk akad yang digunakan di tempat kami yaitu: akad waka>lah yaitu: mewakilkan atau menyerahkan sesuatu pekerjaan atau urusan kepada orang lain. Ketika penjual yang datang ketempat kami untuk menjual motornya, dengan maksud mau menjual motornya ataupun penjual tersebut meminta untuk dicarikan pembeli sepeda motor. ${ }^{32}$

\section{d. Makelar Sepeda Motor Di Bone Bagian Utara}

Pelaksanaan jual beli sepeda motor di tempat kami, bentuk akadnya adalah: akad waka>lah yaitu: mewakilkan atau menyerahkan sesuatu pekerjaan atau urusan kepada orang lain. Misalnya: ada orang yang datang ketempat kami untuk menjual motornya, dan dia minta kepada kami untuk dicarikan pembeli sepeda motor. ${ }^{33}$

Di dalam pelaksanaan jual beli sepeda motor di tempat kami, bentuk akadnya adalah: akad waka>lah yaitu: mewakilkan atau

\footnotetext{
${ }^{30}$ Hasil Wawancara Dengan Anis Amir Pemilik Makelar Sepeda Motor, Pada Hari Sabtu 1 Oktober 2016 Jam 12.30-12.45 WIB, Di Desa Kawarang Kecamatan Cina.

${ }^{31}$ Hasil Wawancara Dengan Herman Pemilik Makelar Sepeda Motor, Pada Hari Sabtu 1 Oktober 2016 Jam 13.00 - 13.15 WIB, Di Kelurahan Tanete Kecamatan Cina.

${ }^{32}$ Hasil Wawancara Dengan Safrinus Pemilik Makelar Sepeda Motor, Pada Hari Sabtu 1 Oktober 2016 Jam 14.00- 14.15 WIB, Di Desa Mario Kecamatan Mare.

${ }^{33}$ Hasil Wawancara Dengan Anwar Pemilik Makelar Sepeda Motor, Pada Hari Rabu 5 Oktober 2016 Jam 10.00 - 10.15 WIB, Di Desa Paccing Kecamatan Awangpone.
} 
menyerahkan sesuatu pekerjaan atau urusan kepada orang lain. ada orang yang datang ketempat kami untuk menjual motornya, dan dia minta kepada kami untuk dicarikan pembeli sepeda motor. ${ }^{34}$

\section{e. Makelar Sepeda Motor Di Bone Bagian Timur}

Dalam pelaksanaan jual beli sepeda motor di tempat kami, bentuk akadnya adalah: akad waka>lah yaitu: mewakilkan atau menyerahkan sesuatu pekerjaan atau urusan kepada orang lain. Penjual datang ketempat kami untuk menjual motornya, dan dia minta kepada kami untuk dicarikan pembeli sepeda motor. ${ }^{35}$

Pelaksanaan jual beli sepeda motor di tempat kami, bentuk akadnya adalah: akad waka>lah yaitu: mewakilkan atau menyerahkan sesuatu pekerjaan atau urusan kepada orang lain. Misalnya: ada orang yang datang ketempat kami untuk menjual motornya, dan dia minta kepada kami untuk dicarikan pembeli sepeda motor. ${ }^{36}$

Dari hal di atas maka Bentuk akad dari transaksi tersebut adalah berbentuk akad waka>lah yaitu: mewakilkan atau menyerahkan sesuatu pekerjaan atau urusan kepada orang. antara kedua belah pihak (pembeli dengan makelar atau penjual dengan makelar) di atas yang saling mengikrarkan. Maka, hal yang demikian ini menjadi perjanjian yang mengikat, dan ikatan inilah yang menjadikan atau mewajibkan bagi seorang makelar untuk menjalankan kewajiban, sebagai perantara dan bertanggungjawab sepenuhnya dalam mencarikan sepeda motor. Transaksi menjadi mengikat

${ }^{34}$ Hasil Wawancara Dengan Rijal Pemilik Makelar Sepeda Motor, Pada Hari Rabu 5 Oktober 2016 Jam 10.30 - 10.45 WIB, Di Desa Paccing Kecamatan Awangpone.

${ }^{35}$ Hasil Wawancara Dengan Indri Pemilik Makelar Sepeda Motor, Pada Hari Sabtu 8 Oktober 2016 Jam 9.30 - 9.45 WIB, Di Kelurahan Lonrae Kecamatan Tanete Riattang Timur.

${ }^{36}$ Hasil Wawancara Dengan Amri Pemilik Makelar Sepeda Motor, Pada Hari Sabtu 8 Oktober 2016 Jam 9.55 - 10.10 WIB, Di Kelurahan Lonrae Kecamatan Tanete Riattang Timur.

Jurnal Ilmiah Al Tsarwah Program Magister Program Studi Ekonomi Syariah Institut Agama Islam Negeri (IAIN) Bone 
ketika pekerjaan selesai dilakukan serta upah telah tetap dan menjadi kewajiban bagi penyewa untuk memberikan upah atas jasa yang di berikan oleh Makelar dalam mencarikan sepeda motor.

\section{KESIMPULAN DAN SARAN}

\section{Kesimpulan}

Berdasarkan hasil analisis dan pembahasan diatas, maka dapat ditarik kesimpulan sebagai berikut:

a. Praktek Makelar Dalam Jual Beli Sepeda Motor Di Kabupaten Bone

Penjual memberikan kuasa sepenuhnya kepada pedagang perantara untuk menjualkan sepeda motor karena penjual tidak ingin repot dengan segala sesuatunya, biasanya penjual hanya ingin langsung mendapat harga penjualan bersih tanpa dipotong dengan biaya-biaya. Dalam hal yang demikian maka penjual tidak perlu bertemu dengan pembeli karena segala sesuatunya akan diuruskan oleh pedagang perantara.

Kegiatan pedagang perantara dalam melakukan transaksi jual beli sangat sederhana karena lebih mengutamakan musyawarah mufakat terhadap pihak pembeli ataupun penjual, ketika ada kesepakatan maka pedagang perantara akan menyiapkan segala sesuatunya untuk mendukung transaksi. Pedagang perantara akan meminta penjual untuk menyiapkan berkas-berkas yang meliputi : (1) Bukti Pemilik Kendaraan Bermotor (BPKB). (2) Surat Tanda Nomor Kendaraan (STNK). (3) Kwitansi tanda beli motor untuk bukti bahwa penjual telah menerima pembayaran dari pembeli dari setiap transaksi 
per unit motor. Rata- rata para makelar sepeda motor di kabupaten bone bekerjasama dengan pembiayaan seperti mandala, adira.

b. Bentuk Akad Dalam Praktek Makelar Dalam Jual Beli Sepeda Motor Di Kabupaten Bone.

Bentuk akad dari transaksi tersebut adalah berbentuk akad waka>lah yaitu: mewakilkan atau menyerahkan sesuatu pekerjaan atau urusan kepada orang. kedua belah pihak (pembeli dengan makelar atau penjual dengan makelar) yang saling mengikrarkan. Maka, hal yang demikian ini menjadi perjanjian yang mengikat, dan ikatan inilah yang menjadikan atau mewajibkan bagi seorang makelar untuk menjalankan kewajiban, sebagai perantara dan bertanggungjawab sepenuhnya dalam mencarikan sepeda motor. Transaksi menjadi mengikat ketika pekerjaan selesai dilakukan serta upah telah tetap dan menjadi kewajiban bagi penyewa untuk memberikan upah atas jasa yang di berikan oleh Makelar dalam mencarikan sepeda motor.

\section{Saran}

1. Kepada para pelaku (penjual, pembeli dan makelar) hendaknya mengetahui masalah fiqh agar memiliki loyalitas yang tinggi terhadap prakteknya sehingga bisa terjauh dari hal-hal yang dilarang oleh agama. Dimana makelar sebagai saran atau media untuk mempermudah jalannya transaksi.

2. Kepada para makelar dipercaya masyarakat sebagai jembatan penghubung dalam transaksi, agar selalu menjaga integritas serta selalu aktif dalam melayani keluhan masyarakat di dalam masalah jual beli sepeda motor dan lebih konsekuen dalam menjaga amanat sebagai orang yang dipercaya. 


\section{DAFTAR PUSTAKA}

Depdikbud, Kamus Besar Bahasa Indonesia, (Jakarta: Balai Pustaka, 1998).

Djuwaini Dimyauddin, pengantar fiqh muamalah, (Cet. 2 ; Yogyakarta : Pustaka Pelajar, 2010).

Emzir, Metodologi Penelitian Kualitatif:Analisis Data, Ed. 1 (Cet. 4 ; Jakarta: Rajawali Pers, 2014).

Ghufron A, Masadi, fiqh muamalah kontekstual, Ed. 1 (Cet. 1; Jakarta: PT Raja Grafindo Persada, 2002).

H. Chairuman Pasaribu, Suhrawardi K.Lubis, Hukum Perjanjian Dalam Islam, (Cet. 3; Jakarata: Sinar Grafika, 2004).

H. Hendi Suhendi, Fiqh Muamalah, Ed. 1 (Cet. 2; Jakarta: PT Raja Grafindo Persada, 1997).

Haroen Nasrun, Fiqh Muamalah, (Cet. 2; Jakarta : gaya media pratama, 2007).

J. Supranto, Proposal Penelitian dengan Contoh, (Cet. 1, Jakarta: Universitas Indonesia, 2004).

Karim Helmi, fiqh muamalah, E. 1 (Cet. 2 ; Jakarta : PT Raja Grafindo Persada, 1997). 
Jurnal Ilmiah Al Tsarwah

Program Magister Program Studi Ekonomi Syariah Institut Agama Islam Negeri (IAIN) Bone 